\title{
Problems and Constraints of Respondents Involved in Contract Farming
}

\section{OPEN ACCESS}

Volume: 7

Issue: 2

Month: October

Year: 2019

P-ISSN: 2321-4643

E-ISSN: 2581-9402

Received: 19.09.2019

Accepted: 24.09.2019

Published: 03.10.2019

Citation:

Harish, N. "Problems and Constraints of Respondents Involved in Contract Farming." Shanlax International Journal of Management, vol. 7, no. 2, 2019, pp. 29-36.

DOI:

https://doi.org/10.34293/ management.v7i2.826

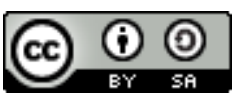

This work is licensed under a Creative Commons Attribution-ShareAlike 4.0 International License.

\section{N.Harish \\ Lecturer, Department of Economics, Adarsha PU College, Bangalore, Karnataka, India}

\begin{abstract}
This article focused on the problems and constraints of respondents involved in contract farming. The study was conducted in two districts of Karnataka state viz., Bangalore Rural and Tumakuru. Two taluks each from each districts, Tumakuru and Gubbi taluks from Tumakuru district and Nelamangala and Doddaballapura taluks from Bangalore Rural district were selected. Keywords: Innovation, Problems, Constraints, Price, Farmers etc.,
\end{abstract}

\section{Introduction}

Contract Farming, in recent decades, has emerged as an institutional innovation for coordinating the agriculture production, processing and marketing operations carried out by different functionaries like farmers, agro-processing firms and marketing agencies. It is an instance of bringing the market to the farmers, which is explored by agribusiness firms. Contract Farming system not only meets the needs of the farmers and agro-processing firms but also empirical research proved that contract farming enhance the agriculture productivity and production.

\section{Methodology}

The methodology used in the study was primary and secondary date. The primary data was collected through structured schedule. Two taluks each from each districts, Tumakuru and Gubbi taluks from Tumakuru district and Nelamangala and Doddaballapura taluks from Bangalore Rural district were selected. Total three crops were selected purposively namely Gherkin, Watermelon, Tomato. The respondents were selected based on simple random sampling techniques; the sample size was Gherkin 35, Tomato 35, Watermelon 10 and non contract farmers 20 from each taluks of two districts.

\section{Problems of Contract Farming}

When asked involved in to contract farmers about any problems faced in growing contract crop under contract, only almost about 51.25 per cent mentioned they did face some problem on contract crop cultivation. This shows a majority of the contract farmers were satisfied with contract farming. Multiple response analysis for the open-ended question on problems faced by respondents and resolving of problems is presented in Table 1. 
International Journal of Management

\begin{tabular}{|c|c|c|c|c|c|c|c|c|c|c|}
\hline \multicolumn{11}{|c|}{ Table Problems Involved in Contract Farming } \\
\hline \multirow{2}{*}{ Indicator } & \multirow{2}{*}{ Particulars } & \multicolumn{2}{|c|}{ Tumakuru } & \multicolumn{2}{|c|}{$\begin{array}{c}\text { Bangalore } \\
\text { Rural }\end{array}$} & \multicolumn{2}{|c|}{ Total } & \multicolumn{3}{|c|}{ Test Statistics } \\
\hline & & No. & $\%$ & No. & $\%$ & No. & $\%$ & $\begin{array}{l}\text { Chi- } \\
\text { Square }\end{array}$ & df & $\begin{array}{c}\text { p } \\
\text { value }\end{array}$ \\
\hline \multirow{10}{*}{$\begin{array}{l}\text { The problems } \\
\text { faced in }\end{array}$} & Lower price of output & 37 & 23.13 & 33 & 20.63 & 70 & 21.88 & \multirow{10}{*}{1.922} & \multirow{10}{*}{9} & \multirow{10}{*}{0.993} \\
\hline & farming & 45 & 28.13 & 37 & 23.13 & 82 & 25.63 & & & \\
\hline & Rejection of output & 41 & 25.63 & 35 & 21.88 & 76 & 23.75 & & & \\
\hline & Higher cost of inputs & 51 & 31.88 & 41 & 25.63 & 92 & 28.75 & & & \\
\hline & Late payments & 96 & 60.00 & 68 & 42.50 & 164 & 51.25 & & & \\
\hline & Lack of flexibility & 90 & 56.25 & 66 & 41.25 & 156 & 48.75 & & & \\
\hline & Fixed rate & 38 & 23.75 & 35 & 21.88 & 73 & 22.81 & & & \\
\hline & $\begin{array}{l}\text { Not enough assistance from } \\
\text { firm }\end{array}$ & 52 & 32.50 & 42 & 26.25 & 94 & 29.38 & & & \\
\hline & Land degradation & 45 & 28.13 & 35 & 21.88 & 80 & 25.00 & & & \\
\hline & Others & 38 & 23.75 & 35 & 21.88 & 73 & 22.81 & & & \\
\hline \multirow{2}{*}{$\begin{array}{l}\text { Solution to } \\
\text { problems }\end{array}$} & $\begin{array}{l}\text { Discussing with the } \\
\text { company representative }\end{array}$ & 55 & 34.38 & 69 & 43.13 & 124 & 38.75 & \multirow[t]{2}{*}{0.837} & \multirow[t]{2}{*}{1} & \multirow[t]{2}{*}{0.36} \\
\hline & Approaching the company & 26 & 16.25 & 24 & 15.00 & 50 & 15.63 & & & \\
\hline
\end{tabular}

Source: Primary Data (Field Survey); Note: Multiple responses

The problems faced in growing the contract crop exhibits that, majority (51.25 per cent) of the respondents are facing the problem of late payment. 48.75 per cent of respondents are facing lack of flexibility. Nearly 29 per cent of respondents are facing problem of not enough assistance from firm. Nearly 28.75 of respondents are facing the problem of higher cost inputs. Approximately 25 per cent of respondents are facing the problems of poor quality of seeds and land degradation and 23 percent of rejection crop, nearly 22 percentage of lower price of inputs and other problems. It is true across the two districts. Moreover, there were few contract farmers even doubting the ethics of contracting firm about whether they report the true weight of seed tubers and output. As some farmers felt that on seeds tubers bag, weight is not mentioned. The p 0.993 value obtained by Chi square statistics test result indicates that, the problems faced in growing the contract crop are independent of districts. The major problems faced by contract farmers are late payments and lack of flexibility.

To resolve the problems faced by contract farmers, majority of (38.75 per cent) of respondents discussing with the company representative, and majority ( 15.63 per cent) of respondents approaching the company to solve their problems. It is seen in the both districts. Both districts respondents are resolving their contract problems in the above mentioned ways. The $\mathrm{p} 0.36$ value obtained by Chi square statistics test result indicates that, methods of resolving the problems are independent across two districts. To solve the problem raised the farmers are discussing with the company representative.

\section{Constraints of Respondents}

To study constraints faced by farmers practicing contract farming as set of 28 statements were developed based on the respondents of the farmers. These were quantified in three points like least, moderate and most. The constraints of respondents are depicted from Table 5.33.

Majority (36.56 per cent) of respondents faced by contract farming constraints is seasonal basis is moderate. It is true in both the districts. It was in Tumakuru district is 38 per cent and in Bangalore rural district is 35.00 per cent. Contract farming is seasonal basis is 34.06 per cent is most and 29.38 per cent is least. The $\mathrm{p} 0.822$ value obtained by Chi square statistics test result indicates that, contract farming is seasonal basis across the district is independent. In the case of degradation of soil fertility and ground 
water pollution almost 35.00 per cent of respondents test result indicates that, degradation of soil fertility faced least constraint. It is true in both the districts. and ground water pollution across the district is The $\mathrm{p} 0.686$ value obtained by Chi square statistics independent.

Table Constraints of Respondents

\begin{tabular}{|c|c|c|c|c|c|c|c|c|c|c|}
\hline \multirow{2}{*}{ Indicator } & \multirow{2}{*}{ Particulars } & \multicolumn{2}{|c|}{ Tumakuru } & \multicolumn{2}{|c|}{$\begin{array}{c}\text { Bangalore } \\
\text { Rural }\end{array}$} & \multicolumn{2}{|c|}{ Total } & \multicolumn{3}{|c|}{ Test Statistics } \\
\hline & & No & $\%$ & No & $\%$ & No & $\%$ & $\begin{array}{l}\text { Chi- } \\
\text { Square }\end{array}$ & df & $\begin{array}{c}\mathbf{p} \\
\text { value }\end{array}$ \\
\hline \multirow{3}{*}{$\begin{array}{l}\text { Contract farming is } \\
\text { seasonal basis }\end{array}$} & Least & 45 & 28.13 & 49 & 30.63 & 94 & 29.38 & \multirow{3}{*}{0.393} & \multirow{3}{*}{2} & \multirow{3}{*}{0.822} \\
\hline & Moderate & 61 & 38.13 & 56 & 35.00 & 117 & 36.56 & & & \\
\hline & Most & 54 & 33.75 & 55 & 34.38 & 109 & 34.06 & & & \\
\hline \multirow{3}{*}{$\begin{array}{l}\text { Degradation of soil fertility } \\
\text { and ground water pollution }\end{array}$} & Least & 55 & 34.38 & 57 & 35.63 & 112 & 35.00 & \multirow{3}{*}{0.755} & \multirow{3}{*}{2} & \multirow{3}{*}{0.686} \\
\hline & Moderate & 51 & 31.88 & 56 & 35.00 & 107 & 33.44 & & & \\
\hline & Most & 54 & 33.75 & 47 & 29.38 & 101 & 31.56 & & & \\
\hline \multirow{3}{*}{$\begin{array}{l}\text { Farmers dependents for } \\
\text { seed on firm }\end{array}$} & Least & 68 & 42.50 & 59 & 36.88 & 127 & 39.69 & \multirow{3}{*}{1.185} & \multirow{3}{*}{2} & \multirow{3}{*}{0.553} \\
\hline & Moderate & 47 & 29.38 & 49 & 30.63 & 96 & 30.00 & & & \\
\hline & Most & 45 & 28.13 & 52 & 32.50 & 97 & 30.31 & & & \\
\hline \multirow{3}{*}{$\begin{array}{l}\text { Inefficiency of organizers/ } \\
\text { middlemen }\end{array}$} & Least & 56 & 35.00 & 50 & 31.25 & 106 & 33.13 & \multirow{3}{*}{0.596} & \multirow{3}{*}{2} & \multirow{3}{*}{0.742} \\
\hline & Moderate & 56 & 35.00 & 57 & 35.63 & 113 & 35.31 & & & \\
\hline & Most & 48 & 30.00 & 53 & 33.13 & 101 & 31.56 & & & \\
\hline \multirow{3}{*}{$\begin{array}{l}\text { Price negotiation is not } \\
\text { competitive }\end{array}$} & Least & 49 & 30.63 & 46 & 28.75 & 95 & 29.69 & \multirow{3}{*}{3.438} & \multirow{3}{*}{2} & \multirow{3}{*}{0.179} \\
\hline & Moderate & 66 & 41.25 & 54 & 33.75 & 120 & 37.50 & & & \\
\hline & Most & 45 & 28.13 & 60 & 37.50 & 105 & 32.81 & & & \\
\hline & Least & 58 & 36.25 & 62 & 38.75 & 120 & 37.50 & & & \\
\hline Delay in settling payment & Moderate & 45 & 28.13 & 42 & 26.25 & 87 & 27.19 & 0.246 & 2 & 0.884 \\
\hline & Most & 57 & 35.63 & 56 & 35.00 & 113 & 35.31 & & & \\
\hline & Least & 56 & 35.00 & 52 & 32.50 & 108 & 33.75 & & & \\
\hline Buyers manipulate & Moderate & 53 & 33.13 & 59 & 36.88 & 112 & 35.00 & 0.51 & 2 & 0.775 \\
\hline & Most & 51 & 31.88 & 49 & 30.63 & 100 & 31.25 & & & \\
\hline Farmers prone to various & Least & 53 & 33.13 & 55 & 34.38 & 108 & 33.75 & & & \\
\hline problems due to regular & Moderate & 53 & 33.13 & 62 & 38.75 & 115 & 35.94 & 1.989 & 2 & 0.37 \\
\hline use of pesticides & Most & 54 & 33.75 & 43 & 26.88 & 97 & 30.31 & & & \\
\hline & Least & 46 & 28.75 & 51 & 31.88 & 97 & 30.31 & & & \\
\hline $\begin{array}{l}\text { Monopoly of contract } \\
\text { farming firm }\end{array}$ & Moderate & 62 & 38.75 & 58 & 36.25 & 120 & 37.50 & 0.401 & 2 & 0.818 \\
\hline & Most & 52 & 32.50 & 51 & 31.88 & 103 & 32.19 & & & \\
\hline & Least & 52 & 32.50 & 52 & 32.50 & 104 & 32.50 & & & \\
\hline $\begin{array}{l}\text { Manipulation of norms by } \\
\text { firm }\end{array}$ & Moderate & 54 & 33.75 & 49 & 30.63 & 103 & 32.19 & 0.464 & 2 & 0.793 \\
\hline & Most & 54 & 33.75 & 59 & 36.88 & 113 & 35.31 & & & \\
\hline & Least & 48 & 30.00 & 53 & 33.13 & 101 & 31.56 & & & \\
\hline Low contract price & Moderate & 56 & 35.00 & 53 & 33.13 & 109 & 34.06 & 0.366 & 2 & 0.833 \\
\hline & Most & 56 & 35.00 & 54 & 33.75 & 110 & 34.38 & & & \\
\hline
\end{tabular}


SHANLAX

International Journal of Management

\begin{tabular}{|c|c|c|c|c|c|c|c|c|c|c|}
\hline \multirow{3}{*}{ High initial investments } & Least & 48 & 30.00 & 40 & 25.00 & 88 & 27.50 & \multirow{3}{*}{5.069} & \multirow{3}{*}{2} & \multirow{3}{*}{0.079} \\
\hline & Moderate & 68 & 42.50 & 57 & 35.63 & 125 & 39.06 & & & \\
\hline & Most & 44 & 27.50 & 63 & 39.38 & 107 & 33.44 & & & \\
\hline \multirow{3}{*}{$\begin{array}{l}\text { High rejection rate by } \\
\text { company }\end{array}$} & Least & 52 & 32.50 & 56 & 35.00 & 108 & 33.75 & \multirow{3}{*}{0.692} & \multirow{3}{*}{2} & \multirow{3}{*}{0.708} \\
\hline & Moderate & 57 & 35.63 & 50 & 31.25 & 107 & 33.44 & & & \\
\hline & Most & 51 & 31.88 & 54 & 33.75 & 105 & 32.81 & & & \\
\hline \multirow{3}{*}{$\begin{array}{l}\text { No compensation for } \\
\text { losses }\end{array}$} & Least & 54 & 33.75 & 45 & 28.13 & 99 & 30.94 & \multirow{3}{*}{1.192} & \multirow{3}{*}{2} & \multirow{3}{*}{0.551} \\
\hline & Moderate & 55 & 34.38 & 59 & 36.88 & 114 & 35.63 & & & \\
\hline & Most & 51 & 31.88 & 56 & 35.00 & 107 & 33.44 & & & \\
\hline \multirow{3}{*}{$\begin{array}{l}\text { Non-availability of loan in } \\
\text { required time and amount }\end{array}$} & Least & 56 & 35.00 & 62 & 38.75 & 118 & 36.88 & \multirow{3}{*}{0.558} & \multirow{3}{*}{2} & \multirow{3}{*}{0.757} \\
\hline & Moderate & 54 & 33.75 & 49 & 30.63 & 103 & 32.19 & & & \\
\hline & Most & 50 & 31.25 & 49 & 30.63 & 99 & 30.94 & & & \\
\hline \multirow{3}{*}{ High interest rate for loan } & Least & 60 & 37.50 & 64 & 40.00 & 124 & 38.75 & \multirow{3}{*}{2.358} & \multirow{3}{*}{2} & \multirow{3}{*}{0.308} \\
\hline & Moderate & 50 & 31.25 & 58 & 36.25 & 108 & 33.75 & & & \\
\hline & Most & 50 & 31.25 & 38 & 23.75 & 88 & 27.50 & & & \\
\hline \multirow{3}{*}{$\begin{array}{l}\text { Non-availability of } \\
\text { technical assistant in } \\
\text { required time }\end{array}$} & Least & 47 & 29.38 & 52 & 32.50 & 99 & 30.94 & \multirow{3}{*}{0.405} & \multirow{3}{*}{2} & \\
\hline & Moderate & 58 & 36.25 & 54 & 33.75 & 112 & 35.00 & & & 0.817 \\
\hline & Most & 55 & 34.38 & 54 & 33.75 & 109 & 34.06 & & & \\
\hline & Least & 47 & 29.38 & 52 & 32.50 & 99 & 30.94 & & & \\
\hline No fixed schedules of visit & Moderate & 42 & 26.25 & 50 & 31.25 & 92 & 28.75 & 2.258 & 2 & 0.323 \\
\hline & Most & 71 & 44.38 & 58 & 36.25 & 129 & 40.31 & & & \\
\hline Lack of training on proper & Least & 64 & 40.00 & 54 & 33.75 & 118 & 36.88 & & & \\
\hline time and methods of & Moderate & 56 & 35.00 & 59 & 36.88 & 115 & 35.94 & 1.489 & 2 & 0.475 \\
\hline harvesting & Most & 40 & 25.00 & 47 & 29.38 & 87 & 27.19 & & & \\
\hline & Least & 66 & 41.25 & 54 & 33.75 & 120 & 37.50 & & & \\
\hline Lack of transportation & Moderate & 57 & 35.63 & 63 & 39.38 & 120 & 37.50 & 1.95 & 2 & 0.377 \\
\hline & Most & 37 & 23.13 & 43 & 26.88 & 80 & 25.00 & & & \\
\hline & Least & 46 & 28.75 & 59 & 36.88 & 105 & 32.81 & & & \\
\hline Lack of storage facility & Moderate & 53 & 33.13 & 52 & 32.50 & 105 & 32.81 & 2.928 & 2 & 0.231 \\
\hline & Most & 61 & 38.13 & 49 & 30.63 & 110 & 34.38 & & & \\
\hline & Least & 49 & 30.63 & 52 & 32.50 & 101 & 31.56 & & & \\
\hline $\begin{array}{l}\text { Non-avallability of inputs } \\
\text { in rioht time }\end{array}$ & Moderate & 59 & 36.88 & 47 & 29.38 & 106 & 33.13 & 2.164 & 2 & 0.339 \\
\hline & Most & 52 & 32.50 & 61 & 38.13 & 113 & 35.31 & & & \\
\hline & Least & 50 & 31.25 & 61 & 38.13 & 111 & 34.69 & & & \\
\hline High cost of inputs & Moderate & 64 & 40.00 & 53 & 33.13 & 117 & 36.56 & 2.124 & 2 & 0.346 \\
\hline & Most & 46 & 28.75 & 46 & 28.75 & 92 & 28.75 & & & \\
\hline & Least & 56 & 35.00 & 52 & 32.50 & 108 & 33.75 & & & \\
\hline Contract being loaded & Moderate & 53 & 33.13 & 52 & 32.50 & 105 & 32.81 & 0.391 & 2 & 0.822 \\
\hline & Most & 51 & 31.88 & 56 & 35.00 & 107 & 33.44 & & & \\
\hline & Least & 50 & 31.25 & 49 & 30.63 & 99 & 30.94 & & & \\
\hline $\begin{array}{l}\text { Lack of domestic market } \\
\text { for the produce }\end{array}$ & Moderate & 51 & 31.88 & 56 & 35.00 & 107 & 33.44 & 0.384 & 2 & 0.825 \\
\hline & Most & 59 & 36.88 & 55 & 34.38 & 114 & 35.63 & & & \\
\hline
\end{tabular}




\begin{tabular}{|c|c|c|c|c|c|c|c|c|c|c|}
\hline \multirow{3}{*}{$\begin{array}{l}\text { Lack of confidence in } \\
\text { farmer firm relationship }\end{array}$} & Least & 52 & 32.50 & 51 & 31.88 & 103 & 32.19 & \multirow{3}{*}{0.391} & \multirow{3}{*}{2} & \multirow{3}{*}{0.823} \\
\hline & Moderate & 58 & 36.25 & 54 & 33.75 & 112 & 35.00 & & & \\
\hline & Most & 50 & 31.25 & 55 & 34.38 & 105 & 32.81 & & & \\
\hline \multirow{3}{*}{$\begin{array}{l}\text { No proper government } \\
\text { support }\end{array}$} & Least & 51 & 31.88 & 57 & 35.63 & 108 & 33.75 & \multirow{3}{*}{0.649} & \multirow{3}{*}{2} & \multirow{3}{*}{0.723} \\
\hline & Moderate & 49 & 30.63 & 49 & 30.63 & 98 & 30.63 & & & \\
\hline & Most & 60 & 37.50 & 54 & 33.75 & 114 & 35.63 & & & \\
\hline \multirow{3}{*}{ No proper legal support } & Least & 51 & 31.88 & 60 & 37.50 & 111 & 34.69 & \multirow{3}{*}{1.281} & \multirow{3}{*}{2} & \multirow{3}{*}{0.527} \\
\hline & Moderate & 51 & 31.88 & 44 & 27.50 & 95 & 29.69 & & & \\
\hline & Most & 58 & 36.25 & 56 & 35.00 & 114 & 35.63 & & & \\
\hline
\end{tabular}

Source: Primary Data (Field Survey)

Majority (40.00 per cent) of respondents constraints are faced by farmer's dependents for seed on firm is least. It is in Tumakuru district is 42.50 per cent and in Bangalore rural district is 36.88 per cent. Constraints are faced by farmer's dependents for seed on firm is 30.00 per cent is most and 30.00 per cent is moderate. The $p 0.553$ value obtained by Chi square statistics test result indicates that, farmer's dependents for seed on firm across the district is independent. In the case of Inefficiency of organizers/middlemen almost 35.31 per cent of respondents faced moderate constraint. It was same in both the districts. The $\mathrm{p} 0.742$ value obtained by Chi square statistics test result indicates that, inefficiency of organizers/middlemen across the district is independent.

The constraints of price negotiation is not competitive majority 37.50 per cent is moderate. In Tumakuru district 41.25 per cent and in Bangalore rural district 33.75 per cent of constraints of price negotiation are moderately not competitive. But in Bangalore rural district 37.50 per cent of price negotiation is most not competitive. The $\mathrm{p} 0.179$ value obtained by Chi square statistics test result indicates that, price negotiation is not competitive across the district is independent. In the case of delay in settling payment constraints result found 37.50 of least constraint. It is true across both districts. The same constraint respondents opinion is 35.31 per cent is most and 27.19 per cent is least constraints. The $\mathrm{p} 0.246$ value obtained by Chi square statistics test result indicates that, Delay in settling payment across the district is independent.

Information was collected from the respondents about buyers manipulate constraint, result found 35.00 per cent is moderate constraint. In Tumakuru district it was 33.13 per cent and in Bangalore rural district 36.88 per cent. This constraint is 33.75 per cent is least and 31.25 per cent is most constraints. The $\mathrm{p} 0.775$ value obtained by Chi square statistics test result indicates that, buyers manipulate across the district is independent. Farmers prone to various problems due to regular use of pesticides constraint is 36 per cent moderate. It was in Tumakuru district is 33.13 per cent and 38.75 per cent is in Bangalore rural district. For the same constraint result found in the study 33.75 per cent is least constraint and 30.31 per cent is most constraint. The $p 0.37$ value obtained by Chi square statistics test result indicates that, farmers prone to various problems due to regular use of pesticides across the district is independent.

In the constraint of monopoly of contract farming firm 37.50 per cent moderate constraint found in the study. It is same in both the districts. The respondents opinion is 32.19 per cent most constraint and 30.31 per cent least constraint. The $\mathrm{p} 0.818$ value obtained by Chi square statistics test result indicates that, monopoly of contract farming firm across the district is independent. In the case of manipulation of norms by firm almost 35.31 per cent of respondents faced most constraint. It was in Tumakuru district is 33.75 per cent and in Bangalore rural district is 36.88 per cent. The manipulation of norms by firm constraint is 32.00 per cent moderate constraints in both the districts. The p 0.793 value obtained by Chi square statistics test result indicates that, manipulation of norms by firm across the district is independent.

Majority (34.00 per cent) of the respondents in the study area faced moderate and lost constraints in the case of low contract price. The respondent's opinion is they are getting low contract price for their crops. It true in both districts and 31.56 is least constraints 
in the study area for low contract price constraint. The $\mathrm{p} 0.833$ valueobtained by Chi square statistics test result indicates that, low contract price across the district is independent. The constraint of high initial investment majority 39.06 per cent of respondent's constraint of contract farming is moderate. It was in Tumakuru district is 42.50 per cent and in Bangalore rural district is 35.63 per cent. This high initial investment constraint found in the study area 33.44 per cent most and 27.50 per cent is least constraint. The $\mathrm{p} 0.079$ value obtained by Chi square statistics test result indicates that, high initial investments across the district are independent. The constraint of high rejection rate by company, result found that, 33 per cent is least and moderate constraint. It was same in both districts. Only 32.81 per cent is most constraint of high rejection rate by company. The p 0.708 value obtained by Chi square statistics test result indicates that, high rejection rate by company across the district is independent.

In the case of no compensation for losses by firm almost 35.63 per cent of respondents opinion is moderate constraint. It is same in both the districts. The $\mathrm{p} 0.551$ value obtained by Chi square statistics test result indicates that, no compensation for losses across the district is independent. Non availability of loan in required time and amount contract farming constraint is 36.88 per cent least in the study area. It was in Tumakuru district is 35.00 per cent and 38.75 per cent is in Bangalore rural district. 31.00 per cent is most constraint. The p 0.757 value obtained by Chi square statistics test result indicates that, nonavailability of loan in required time and amount across the district is independent.

In the case of high interest rate for loan almost 38.75 per cent of respondent's opinion is least constraint on contract farming. It was in Tumakuru district is 37.50 per cent and in Bangalore rural district is 40.00 per cent. This constraint is 34.00 per cent moderate and 28.00 per cent is least constraint. The $\mathrm{p} 0.308$ value obtained by Chi square statistics test result indicates that, high interest rate for loan across the district is independent. The constraint of non availability of technical assistant in requires time majority 35.00 per cent of respondent's constraint of contract farming is moderate. It is same in both the districts. This constraint is 34.06 per cent most and
31.00 per cent least constraint. The p 0.817 value obtained by Chi square statistics test result indicates that, non-availability of inputs in right time across the district is independent.

No fixed schedules of visit by extension workers contract farming constraint is 40.13 per cent most in the study area. It was in Tumakuru district is 44.38 per cent and 36.25 per cent is in Bangalore rural district. This constraint is 30.90 per cent is least constraint and 27.00 per cent is most constraint in the study area. The p 0.323 value obtained by Chi square statistics test result indicates that, no fixed schedules of visit by extension workers across the district is independent. The constraint lack of training on proper time and methods of harvest majority 36.88 per cent of respondent's constraint of contract farming is least. It was in Tumakuru district is 40.00 per cent and in Bangalore rural district is 34.00 per cent. This lack of training on proper time and methods of harvest found in the study area 36.00 per cent moderate and 27.00 per cent is most constraint. The $\mathrm{p} 0.475$ value obtained by Chi square statistics test result indicates that, lack of training on proper time and methods of harvesting across the district is independent.

Almost 37.50 per cent of respondents are least and moderate constraint on lack of transportation facilities in contract farming practice and 25.00 per cent is most constraint. The $\mathrm{p} 0.377$ value obtained by Chi square statistics test result indicates that, lack of transportation facilities across the district is independent. Regarding lack of storage facility constraint of contract farmers is majority 34.28 per cent of most constraint. It was in Tumakuru district is 38.13 per cent and in Bangalore rural district is 30.63 per cent. This constraint is in the study area 32.81 per cent of least and moderate. The p 0.231 value obtained by Chi square statistics test result indicates that, lack of storage facility across the district is independent.

Majority (35.31 per cent) of respondents constraints are faced by farmer's non availability of inputs in right time is most constraint. It is in Tumakuru district is 32.50 per cent and in Bangalore rural district is 38.13 per cent. Constraints are faced by non availability of inputs in right time is 33.13 per cent is moderate and 31.56 per cent is least. The 
p 0.339 value obtained by Chi square statistics test result indicates that, non-availability of inputs in right time across the district is independent. High cost of inputs constraint is 34.69 per cent is moderate. It was in Tumakuru district is 40.00 per cent and in Bangalore rural district is 33.13. This constraint is more in Tumakuru and less in Bangalore rural district. High cost of inputs constraint is 34.69 per cent of least and 28.75 per cent most constraint based on respondents opinion. The p 0.396 value obtained by Chi square statistics test result indicates that, high cost of inputs across the district is independent.

Contract being loaded against interest of farmer's constraint is almost 33.75 per cent. In Tumakuru district this constraint is 35 per cent of least, and In Banaglore rural district is 32.00 per cent. Contract being loaded against interest of farmer's constraint is in the study area 33.44 per cent of most and 32.81 per cent of moderate. The p 0.391 value obtained by Chi square statistics test result indicates that, contract being loaded against interest of farmers across the district is independent. Lack of domestic market for the produce constraint is 35.63 per cent of most. The same result is found in both the district. This constraint was 33.44 per cent of moderate and 31.00 per cent of least constraint. The p 0.825 value obtained by Chi square statistics test result indicates that, lack of domestic market for the produce across the district is independent.

Lack of domestic confidence in farmer firm relationship constraint is 35.00 per cent of moderate and least. The same result is found in both the district. This constraint was 33.44 per cent of most constraint. The p 0.823 value obtained by Chi square statistics test result indicates that, lack of confidence in farmer firm relationship across the district is independent. The constraint no proper government support majority 35.63 per cent of respondent's has constraint of contract farming is most. It was in Tumakuru district is 37.50 per cent and in Bangalore rural district is 33.75 per cent. This no proper government support result found in the study area 33.75 per cent moderate and 30.63 per cent is least constraint. The $\mathrm{p} 0.475$ value obtained by Chi square statistics test result indicates that, no proper government support across the district is independent. Regarding no proper legal support constraint of contract farmers is majority 35.63 per cent of most constraint. This constraint is in the study area 35.00 per cent of least and moderate constraint. The $\mathrm{p} 0.527$ value obtained by Chi square statistics test result indicates that, no proper legal support across the district is independent.

\section{Conclusion}

The income of respondents increased after joining contract farming, because it gives assured price to crops and market. The profit of famers almost increased after joining contract farming. Savings and investment practice is improved by the farmers. But also contract farmers suffered from some problems and constraints in practicing in contract farming.

\section{References}

Gulati, A., Joshi, P.K. and Landes, M. Contract Farming in India: A Resource Book, National Centre for Agricultural Economics and Policy Research, 2008.

Baumann, Pari. Equity and Efficiency in Contract Farming Schemes: The Experience of Agricultural Tree Crops, Overseas Development Institute, London, 2000.

Birthal, Pratp. Making Contract Farming Work in Smallholder Agriculture, National Centre for Agricultural Economics and Policy Research, New Delhi, 2007.

Grossman, LS. The Political Ecology of Bananas: Contract Farming, Peasants and Agrarian Change in the Eastern Caribbean, University of North Carolina Press, Chaperl Hill and London, 1998.

Gupta. "Respinning Strategies." Contract Farming in India an Introduction, edited by Rajmanohar, TP and Kumaravel, KS, The ICFAI University Press, Agartala, 2006.

Hamilton, ND. "Agricultural Contracting: A U.S. Perspective and Issues for India to Consider." Contract Farming in India: A Resource Book, edited by Gulati, A, Joshi, PK and Landes, M, 2008.

Jackson, JC and Cheater, AP. "Contract Farming in Zimbabwe: Case Studies of Sugar, Cotton and Tea." Living Under Contract: Contract Farming and Agrarian Transformation in Sub Saharam Africa, edited by Little, PD and 
Watts, MJ. Madison, University of Wisconsin Press, 1994.

Jain, RCA. Regulation and Disputes Settlement in Contract Farming in India: A Resource Book, ICAR, IFPRI, USPA, New Delhi, 2008.

Little, PD. Living under Contract: Contract Farming and Agrarian Transformation in Sub Saharam Africa, University of Wisconsin Press, Madison, 1994.

Mahendra Dev, S and Chandrasekhara Rao, N. "Food Processing and Contract Farming in Andra Pradesh: A Small Farmer Perspective." Economic and Political Weekly, vol. 40, no. 26, 2005, pp. 2705-2713.

Meti, M, Sureshaand, SV and Raghuprasad, KP. "Impact of Contract Farming on Economic Status of Farmers in Karnataka." Journal of Rural Development, vol. 32, no. 2, 2013, pp. 201-212.

Manage. "Contract Farming Ventures in India: A Few Successful Cases.” Spice, vol. 1, no. 4, 2003, pp. 1-6.

Manjunath, AV, Ramappa, KB, Lavanya, BT and Mamatha, NC. "Present Status and Prospectus of Contract Farming in India." International Journal of Agriculture Science, vol. 8, no. 7, 2016, pp. 1072-1075.

McLeod, WB. "Reputations Relationship and Contracts Enforcement." Journal of Economic Literature, vol. 45, no. 3, 2007, pp. 595-628.

Memon, IN, Wagan, H, Noonari, S, Lakhio, MH and Lanjar, BA. "Economic Analysis of Banana Production under Contract Farming in Sindh Pakistan." Journal of Marketing and Consumer Research, vol. 21, 2016, pp. 14-21. Minot, N, Epprecht, M, Tram Anh, TT and Trung, LQ. Income Diversification and Poverty in the Northern Uplands of Vietnam, International
Food Policy Research Institute, Washington, 2006.

Miyata, S, Minot, N and Hu, D. Impact of contract farming on Income, International Food Policy Research Institute, Discussion Paper 00742, Washington, 2007

Murthy, MRK and Bindu Madri, S. "A Case Study on Suguna Poultry Production through Contract Farming in Andra Pradesh." Asia Pacific Journal of Marketing and Management Review, vol. 2, no. 5, 2013, pp. 58-68.

Nagaraj, N, Chandrakanth, MG, Chengappa, PG, Roopa, HS and Chandakavate, PM. "Contract Farming and its Implications for Input-supply, Linkages between Markets and Farmers in Karnataka." Agricultural Economics Research Review, vol. 21, 2008, pp. 307-316.

Nagraj, N, Chandrakanth, MG and Gacy, CP. Contract Farming and Related Issues, University of Agricultural Sciences Bangalore, 2008.

"NSS Report No.492. Some Aspects of Operational Landholdings in India, 2002-03." National Sample Survey Organization. Ministry of Statistics and Program Implementation. Government of India, 2006.

Parirenyatwa, KT and Mago, S. "Evolution and Development of Contract Farming in Zimbabwe: A reflection for Agribusiness." Mediterranean Journal of Social Science, vol. 5, no. 20, 2014, pp. 237-244.

Rajmanohar, TP and Kumaravel, KS. Contract Farming in India - An Introduction, ICFAI University Press, 2006.

Rangi, PS and Sidhu, MS. "A Study on Contract Farming of Tomato in Punjab." Agricultural Marketing, vol. 42, no. 4, 2000, pp. 15-23.

Roy and Poul E. Contract Farming. The Interstate Printers and Piblishers Inc., Illinois, 1963.

\section{Author Details}

Dr.N.Harish, Lecturer, Department of Economics, Adarsha PU College, Bangalore, Karnataka, India.

Email ID: hariniki14@gmail.com. 